\title{
Irrigation Method and Rowcover Use for Strawberry Freeze Protection
}

\author{
George J. Hochmuth ${ }^{1}$, Salvadore J. Locascio ${ }^{2}$, Stephen R. Kostewicz ${ }^{3}$, and Frank G. Martin ${ }^{4}$ \\ Institute of Food and Agricultural Sciences, University of Florida, Gainesville, FL 32611 \\ Additional index words. Fragaria xananassa, sprinkler irrigation, drip irrigation, frost protection
}

\begin{abstract}
Three irrigation treatments (none, drip, and sprinkler) and eight rowcover treatments were evaluated for their capacity to provide freeze protection for strawberries (Fragaria $\times$ ananassa Duch.) in a split-plot factorial field experiment. The period under study included 20 freeze events, two events with minima of $\mathbf{- 9 . 5 C}$ and $\mathbf{- 1 0 . 0 C}$. With no freeze protection, up to $93 \%$ of the flowers were damaged by freezes. Among sprinkler-irrigated plants, an average of only $10 \%$ flowers were damaged due to the freezes. Heavy-weight rowcovers (polyethylene blanket and polypropylene, 30 and $50 \mathrm{~g} \cdot \mathrm{m}^{-2}$, respectively) protected strawberry flowers as well as sprinkler irrigation to $\mathbf{- 4 . 4 C}$. Early yield (December-January) from unprotected plants was negligible. Early yields from plants protected with a 3.2-mm polyethylene blanket or a $50 \mathrm{~g} \cdot \mathrm{m}^{-2}$ polypropylene cover were equal to yields obtained with sprinkler-protected plants. Combinations of sprinkler and certain rowcover treatments provided for better fruit production than either treatment alone. Drip irrigation alone provided no protection from freezes. All strawberry plants recovered from freeze damage and total-season yields were similar with all irrigation methods and rowcovers.
\end{abstract}

Strawberries are produced on 2100 ha in Florida using the annual-hill system with polyethylene-mulched beds (Hochmuth, 1988). Most of the crop is produced in central Florida, and is harvested from December through April. During the colder months (December through February), plants, flowers, and fruits are subject to periodic freezing temperatures. Overhead sprinkler irrigation provides effective protection from freeze damage (Locascio et al., 1967) and is a standard practice.

Although sprinkler irrigation is recommended widely for frost protection for strawberries, it is not without problems. Under very cold and windy (advective) freezes, the increased demand for water can exceed the pumping capacity on many farms. Sprinkler irrigation is not generally effective for frost protection for advective freezes with wind speeds above $16.7 \mathrm{~km} \cdot \mathrm{h}^{-1}$ (Harrison et al., 1974) due to evaporational cooling and suboptimal water coverage of plants. Prolonged sprinkler irrigation also may cause watersoaking damage of fruit, fruit cracking, fertilizer nutrient leaching, soil erosion, and significant losses of fruit to rot.

Urbanization in the major strawberry producing regions of Florida is placing increased demands on the water supply so that the availability of an adequate and dependable water supply for freeze protection is in question. Alternative systems for freeze protection that reduce water use are needed for strawberries. Rowcovers have been used since the early 1960s to enhance vegetable growth rate and provide some frost protection (Wells and Loy, 1985). Light-weight, floating rowcovers currently in use provide growth enhancement, but little significant freeze protection. The objective of this research was to evaluate various types of light and heavy-weight floating rowcovers, used alone and in combination with sprinkler or drip irrigation, for freeze protection of strawberries.

Received for publication 29 July 1992. Accepted for publication 27 Jan. 1993. Florida Agricultural Experiment Station Journal Series No. R-01404. The cost of publishing this paper was defrayed in part by the payment of page charges. Under postal regulations, this paper therefore must hereby be marked advertisement solely to indicate this fact.

${ }^{1}$ Professor, Horticultural Sciences Dept.

${ }^{2}$ Professor, Horticultural Sciences Dept.

${ }^{3}$ Associate Professor, Horticultural Sciences Dept.

${ }^{4}$ Professor, Dept. of Statistics.

\section{Materials and Methods}

This experiment was conducted at the Univ. of Florida Horticultural Research Unit, Gainesville, during Winter 1985-1986 on a level Arrendondo fine sandy soil (loamy, siliceous, hyperthermic, Grossarenic Paleudults). The soil ( $\mathrm{pH}=7.2$ in 2 water : 1 soil) was fertilized by incorporating $\mathrm{N}, \mathrm{P}, \mathrm{K}$, and a micronutrient mix at 88 , 47,72 , and $34 \mathrm{~kg} \cdot \mathrm{ha}^{-1}$, respectively. These amounts of nutrients represented $40 \%, 100 \%, 40 \%$, and $100 \%$ of $\mathrm{N}, \mathrm{P}, \mathrm{K}$, and micronutrients applied, respectively. The remaining $\mathrm{N}$ and $\mathrm{K}(132 \mathrm{~N}-\mathrm{OP}-$ $108 \mathrm{~K}, \mathrm{~kg} \cdot \mathrm{ha}^{-1}$ ) fertilizers were applied in 20 equal amounts weekly via drip irrigation. Following the initial fertilization, the soil in the beds was fumigated withmethyl bromide-chloropicrin (67\%-33\% mixture) at the broadcast rate of $400 \mathrm{~kg} \cdot \mathrm{ha}^{-1}$. Soil was formed into beds $15 \mathrm{~cm}$ high and $60 \mathrm{~cm}$ wide on 1.2-m centers and covered with black polyethylene mulch.

The study was a split-plot experiment in randomized completeblock design with four blocks. Main plots were three irrigation methods (no irrigation, drip irrigation, or sprinkler irrigation) operated during each freeze event. Sub-plot treatments were eight rowcovers (Table 1) deployed before each freeze event. Each subplot consisted of three adjacent strawberry beds $6.1 \mathrm{~m}$ long, with the center bed used for data collection.

Micro (drip) irrigation tubing was placed under the mulch on the bed surface in the bed center of all plots to supply water and fertilizer to the plants and for supplying water to specific main plot treatments during freeze events. Drip emitters were spaced at 30.5$\mathrm{cm}$ intervals along the tubing and each emitter applied $62 \mathrm{ml}$ water/ $\mathrm{h}$ at $55 \times 10^{3} \mathrm{~Pa}$. The drip irrigation system was operated for $1 \mathrm{~h}$ when needed for irrigation to apply the equivalent of one-half pan evaporation irrigation water (calculated on total plot area basis). The same drip irrigation system was run continuously however, for specific treatments during freeze events. Revolving, sprinkler irrigation nozzles (four nozzles per main plot) were positioned to apply $6.4 \mathrm{~mm}$ water/h uniformly during freeze events.

'Douglas' strawberry plants were transplanted on 25 Oct. 1985 in double rows on each bed with $30 \mathrm{~cm}$ between rows and $30 \mathrm{~cm}$ between plants in a row. Overhead sprinkler irrigation was used on all plots periodically during the first 2 weeks after transplanting to aid in transplant establishment.

Rowcovers were placed in the plots by early December by 
Table 1. Rowcover materials evaluated in strawberry freeze protection studies, Gainesville, Fla., Dec.-Apr. $1985-86$.

\begin{tabular}{|c|c|c|c|c|}
\hline Treatment & $\begin{array}{c}\text { Rowcover } \\
\text { material }\end{array}$ & Abbreviation & $\begin{array}{l}\text { Weight or } \\
\text { thickness }^{2}\end{array}$ & Source ${ }^{y}$ \\
\hline 1 & Check (no cover) & & & \\
\hline 2 & $\begin{array}{l}\text { Polypropylene/polyamide } \\
\text { (nonwoven) }\end{array}$ & PA & $15 \mathrm{~g} \cdot \mathrm{m}^{-2}$ & $\begin{array}{l}\text { CDK International, } 3191 \text { Wicks Creek } \\
\text { Tr., Marietta, GA } 30062\end{array}$ \\
\hline 3 & Polypropylene \#1(nonwoven) & PP1 & $17 \mathrm{~g} \cdot \mathrm{m}^{-2}$ & $\begin{array}{l}\text { Kimberly Clark Corp., } 1400 \text { Holcomb } \\
\text { Bridge Rd., Roswell, GA } 30076\end{array}$ \\
\hline 4 & Polypropylene \#2 (nonwoven) & $\mathrm{PP} 2$ & $30 \mathrm{~g} \cdot \mathrm{m}^{-2}$ & \\
\hline 5 & Polypropylene \#3 (nonwoven) & PP3 & $50 \mathrm{~g} \cdot \mathrm{m}^{-2}$ & \\
\hline 6 & Polyester (nonwoven) & $\mathrm{PE}$ & $17 \mathrm{~g} \cdot \mathrm{m}^{-2}$ & $\begin{array}{l}\text { Reemay, Inc., P.O. Box 511, Old } \\
\text { Hickory, TN } 37138\end{array}$ \\
\hline 7 & Polyethylene tunnel (perforated) & PT & $0.28 \mathrm{~mm}$ & $\begin{array}{l}\text { Agplast, Inc., P.O. Box } 318 \text {, Ellenton, } \\
\text { FL } 33532\end{array}$ \\
\hline 8 & Polyethylene blanket & PB & $3.2 \mathrm{~mm}$ & $\begin{array}{l}\text { Industrial Pkg Materials, P.O. Box 1702, } \\
\text { Eaton Park, FL } 33801\end{array}$ \\
\hline
\end{tabular}

$\overline{{ }^{2}}$ Treatments $2,3, \overline{6}$, and 7 are considered to be light covers and treatments 4,5 and 8 are heavy covers.

${ }^{y}$ Mention of a trade name or specific source does not constitute an endorsement over similar products or sources.

covering one edge with soil and furling the cover in an alley. Covers were large enough to enclose all plants in the three-bed plots. Shielded thermocouples (copper-constantan) were placed $7.5 \mathrm{~cm}$ above the mulch in the plant crown area and air temperatures were recorded for all treatments continuously during most freeze events by a data logger.

Rowcovers were deployed during the afternoon preceding an expected freeze event by covering the plants and anchoring the cover with tile weights. Irrigation was initiated when air temperature at $5 \mathrm{~cm}$ above the bed of an uncovered, unirrigated plot fell to 0C. Irrigation was discontinued when the wet bulb air temperature rose above $0 \mathrm{C}$ and ice began to melt. Rowcovers were removed after ice had melted.

Damage to flowers (blackened pistils) due to freezing was evaluated on 22 and 28 Dec.; 6, 17, and 29, Jan.; 21 Feb.; and 5 Mar. Plants that lost flowers to successive freezes produced few flowers before another freeze event. Therefore, counts of frozen and uninjured flowers were converted to percentages to reduce bias in comparisons between plots having few flowers and those having many.

Plants were evaluated on two occasions (5 Feb. and 1 May) for number of leaves, leaf area (portable leaf area meter), and plant (above-ground) dry weight. Leaf samples (most-recently matured leaf) were analyzed for $\mathrm{N}$ by a micro-Kjeldahl procedure, and for $\mathrm{P}, \mathrm{K}, \mathrm{Ca}$, and $\mathrm{Mg}$ by plasma emission spectroscopy following dry ashing. These measurements were made so that we could determine the relative nutrient status and growth of plants receiving different amounts of water due to irrigation for freeze protection.

Mature strawberry fruits (at least $75 \%$ red color) were harvested thrice weekly and graded to determine marketable, cull, and number and weight of freeze-damaged fruit. Culls included fruits poorly shaped or rotten, exclusive of freeze damage. Harvest extended from 30 Dec. 1985 through 1 May 1986. Yields from December through January were considered early. Yield data were tested using analysis of variance. Treatment means (when F-test was significant) were compared using Dunnett's test (one-tailed) and Tukey's $w$ procedure (Steel and Torrie, 1960). Comparisons were made of rowcover means with the no cover (control) within an irrigation treatment using Dunnett's test. Then, using Tukey's $w$ procedure, comparisons were made among the seven rowcover treatments. The same approach was used for irrigation means.

\section{Results}

Air temperatures were at or below freezing for at least 6 h 20 times during Winter 1985-1986 (Table 2). Rowcovers were deployed for each of the 20 freezes. Each freeze was anticipated and covers were not deployed unless a freeze was predicted. The lowest temperatures (-9.5C and-10.0C) were recorded on $26 \mathrm{Dec}$. 1985 and 28 Jan. 1986, respectively. Irrigation and rowcover treatments had significant effects on most variables measured and their interactions were generally significant.

Table 2. Description of freeze events from 15 Dec. 1985 through 29 Jan. 1986 at Gainesville, Fla.

\begin{tabular}{|c|c|c|}
\hline $\begin{array}{l}\text { Freeze } \\
\text { night }\end{array}$ & $\begin{array}{c}\text { Time below } \\
\text { OC (h) }\end{array}$ & $\begin{array}{l}\text { Lowest air } \\
\text { temp }\left({ }^{\circ} \mathrm{C}\right)\end{array}$ \\
\hline \multicolumn{3}{|l|}{ Dec. 1985} \\
\hline $15-16$ & 12 & -4.4 \\
\hline $16-17$ & 8 & -0.6 \\
\hline $17-18$ & 8 & -0.6 \\
\hline $19-20$ & 8 & -1.1 \\
\hline $21-22$ & 11 & -3.3 \\
\hline $25-26$ & 14 & -9.5 \\
\hline $26-27$ & 16 & -6.7 \\
\hline $27-28$ & 6 & -0.6 \\
\hline $30-31$ & 8 & -2.2 \\
\hline \multicolumn{3}{|l|}{ Jan. 1986} \\
\hline $5-6$ & 8 & -3.3 \\
\hline $13-14$ & 10 & -3.3 \\
\hline $27-28$ & 16 & -10.0 \\
\hline 28-29 & 12 & -2.8 \\
\hline \multicolumn{3}{|l|}{ Feb. 1986} \\
\hline $10-11$ & $--^{y}$ & 0 \\
\hline $12-13$ & --- & 0 \\
\hline 24-25 & -- & -3.3 \\
\hline \multicolumn{3}{|l|}{ Mar. 1986} \\
\hline 28 Feb.-1 Mar. & --- & -3.3 \\
\hline 2 & -- & -0.6 \\
\hline $21-22$ & --- & -2.2 \\
\hline $22-23$ & $\cdots$ & -0.6 \\
\hline
\end{tabular}

${ }^{\bar{z}}$ Measured $5 \mathrm{~cm}$ above bed surface of uncovered, unirrigated treatment. yTime not recorded. 
Flower damage. Frozen flowers were counted on 22 Dec. following five freeze events of $-4.4,-0.6,-0.6,-1.1$, and $-3.3 \mathrm{C}$ (Table 2). During the night of 19-20 Dec., when the air reached $1.1 \mathrm{C}$, temperatures in the uncovered plant crown area reached a low of 0C. All covers, with or without irrigation, maintained air temperatures in the plant crown above 0C (data not shown). Temperatures of crowns in the uncovered area dropped to almost $-4 \mathrm{C}$ on the night of 21-22 Dec. (Fig 1). Air temperatures in the plant crown under light-weight covers (PT, PP1, PE, and PA) with drip irrigation or with no irrigation approached freezing. Air temperature under at least one cover (PT) reached freezing, while those under other light-weight covers reached a low of about $2 \mathrm{C}$. All heavy-weight covers (PP2, PP3, and PB) maintained the air near the crown above 3C. Sprinkler irrigation alone maintained the temperature at or above $0 \mathrm{C}$ and, in combination with covers, maintained the temperature at or above $3 \mathrm{C}$ with light covers and $5 \mathrm{C}$ with heavy covers.

Irrigation method and rowcover interacted in their effects on

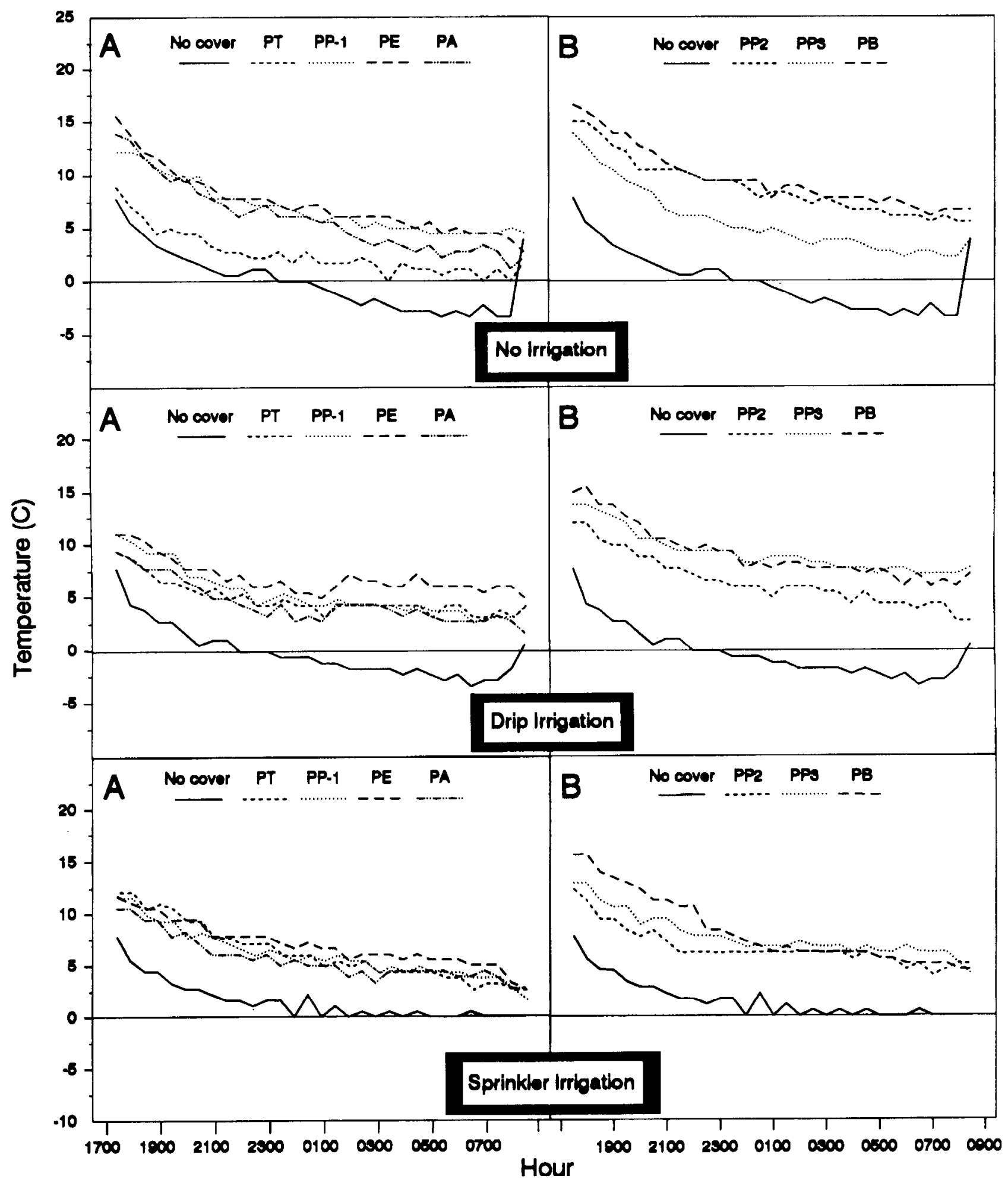

Fig. 1. Effects of irrigation method and light- (A) or heavy- (B) weight rowcovers on air temperature in strawberry plant crown area for 21-22 Dec. 1985. 
Table 3. Interaction effects of irrigation methods and rowcover types on percentage of flowers damaged by freezes during 15 to 22 Dec. 1985.

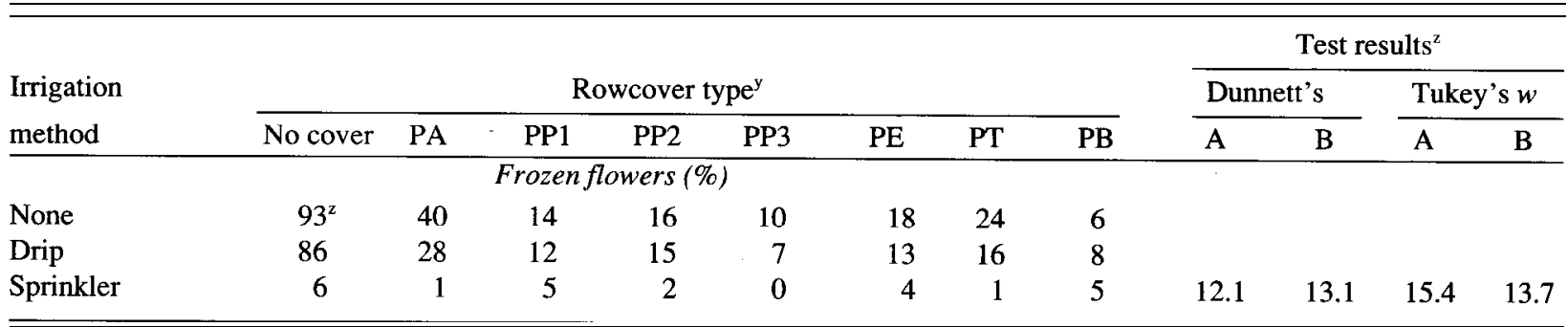

${ }^{2}$ Dunnett's values for (A) comparing rowcover means vs. no cover at an irrigation treatment and (B) for comparing irrigation means vs. no irrigation at a level of rowcover. Tukey's w procedure for (A) comparisons among the seven ranked rowcover means at an irrigation level and (B) for comparing two irrigation means at same or different levels of rowcover. All at $P \leq 0.05$.

${ }^{y}$ Rowcovers described in Table 1 .

percentage of frozen flowers at the 22 Dec. evaluation (Table 3). Although evaluations of flower damage were made on other dates, the results were similar to those obtained on $22 \mathrm{Dec}$. Data for the 28 Dec. evaluation have been reported (Hochmuth et al., 1986). With no protection, 93\% of the flowers were lost to freezing between 15 and 22 Dec. (Table 3).

With no irrigation or with drip irrigation, all rowcovers protected flowers better than no cover. All rowcovers, except PT, provided more protection than PA, and PB and PP3 were significantly better than PT. With drip irrigation, PA performance was poor compared to the other covers. Data taken after the $22 \mathrm{Dec}$. freeze showed that there was little benefit from operating the drip irrigation system during freezes.

When sprinklers were used with or without a rowcover, negligible flower damage resulted. Several covers used alone (PP1, PP2, PP3, PE, and PB) protected strawberry flowers as well as sprinkler irrigation (Tukey's w value $=13.7$ ).

Number of leaves and leaf area. Irrigation method and rowcover did not affect the number of leaves or leaf area on the first sample date (5 Feb. mid season). Plants averaged 25 leaves and $1020 \mathrm{~cm}^{2}$ of leaf area. Irrigation method and rowcover affected leaf count and leaf area significantly on the second sampling made on 1 May 1986 (last harvest). Plants that received no irrigation had more leaves (155) and leaf area $(2780 \mathrm{~cm}$ ') than plants that received drip irrigation or sprinkler irrigation during the freezes. The latter two treatments averaged 135 leaves and $2300 \mathrm{~cm}^{2}$ of leaf area. With rowcovers $\mathrm{PB}$ and $\mathrm{PP} 2$, fewer leaves and less leaf area were recorded than with the other rowcovers (data not shown).

Plant dry weight. Plant dry matter averaged 14.9 and $46.6 \mathrm{~g} /$ plant on 5 Feb. and 1 May, respectively. These data reflect trends similar to those obtained for leaf area data. Plants that produced fruit under freeze protection were significantly smaller than those plants exposed to freezing temperatures that resulted in flower loss. The unprotected plants, lacking a reproductive sink, continued to grow vegetatively.

Leaf $N$ and $K$. Leaf $N$ concentrations were 33.0, 28.0, and 23.1 $\mathrm{g} \cdot \mathrm{kg}^{-1}$ on the 6 Jan., 10 Mar., and 5 May samplings respectively. Leaf $\mathrm{K}$ concentrations were $21.0,19.2$, and $15.1 \mathrm{~g} \cdot \mathrm{kg}^{-1}$ on these same dates, respectively. Although significant treatment effects were present, they were slight and leaf nutrient concentrations were above critical nutrient levels for strawberries (Albregts and Howard, 1984; Hochmuth et al., 1991). Although water amounts applied to various treatments differed (due to freeze protection treatment), nutrient leaching was evidently not a problem because the plants contained adequate concentrations of nutrients. Therefore, evaluations of treatment effects were not confounded with varying nutritional status.

Early yield. Irrigation and rowcovers influenced early fruit yields significantly. Irrigation and rowcover interacted in their effects on yield of marketable fruits and amount of freeze-damaged fruits (Table 4).

Without irrigation, only $\mathrm{PB}, \mathrm{PP} 1$, and $\mathrm{PP} 3$ provided better

Table 4. Interaction of irrigation and rowcover treatments for freeze protection on yield of strawberries, Gainesville, Fla.

\begin{tabular}{|c|c|c|c|c|c|c|c|c|c|c|c|c|c|}
\hline \multirow[b]{3}{*}{ Fruit (t.ha $\left.{ }^{-1}\right)$} & \multirow{3}{*}{$\begin{array}{l}\text { Irrigation } \\
\text { method }\end{array}$} & \multirow{2}{*}{\multicolumn{8}{|c|}{ Rowcover type ${ }^{y}$}} & \multicolumn{4}{|c|}{ Test results ${ }^{z}$} \\
\hline & & & & & & & & & & \multicolumn{2}{|c|}{ Dunnett's } & \multicolumn{2}{|c|}{ Tukey's $w$} \\
\hline & & No cover & PA & PP1 & PP2 & PP3 & $\mathrm{PE}$ & PT & $\overline{\mathrm{PB}}$ & A & $\overline{\mathbf{B}}$ & A & $\bar{B}$ \\
\hline \multicolumn{14}{|c|}{ Early (December-January) harvests } \\
\hline \multirow[t]{3}{*}{ Marketable } & None & 0.02 & 0.08 & 0.68 & 0.37 & 0.57 & 0.20 & 0.28 & 0.96 & & & & \\
\hline & Drip & 0.00 & 0.22 & 0.46 & 0.66 & 1.05 & 0.56 & 0.38 & 0.55 & & & & \\
\hline & Sprinkler & 0.73 & 1.55 & 0.84 & 1.06 & 1.32 & 0.90 & 1.23 & 1.38 & 0.51 & 0.53 & 0.65 & 0.55 \\
\hline \multirow[t]{3}{*}{ Freeze-damaged } & None & 0.00 & 0.02 & 0.09 & 0.03 & 0.07 & 0.07 & 0.08 & 0.09 & & & & \\
\hline & Drip & 0.00 & 0.08 & 0.08 & 0.06 & 0.11 & 0.07 & 0.10 & 0.11 & & & & \\
\hline & Sprinkler & 0.13 & 0.10 & 0.09 & 0.09 & 0.11 & 0.13 & 0.13 & 0.10 & 0.07 & 0.07 & 0.09 & 0.07 \\
\hline \multicolumn{14}{|c|}{ Total season } \\
\hline \multirow[t]{3}{*}{ Freeze-damaged } & None & 0.24 & 1.22 & 1.35 & 1.16 & 1.28 & 0.90 & 1.23 & 1.65 & & & & \\
\hline & Drip & 0.20 & 1.24 & 1.42 & 1.13 & 1.40 & 1.48 & 1.38 & 1.27 & & & & \\
\hline & Sprinkler & 1.58 & 2.30 & 1.67 & 1.88 & 2.73 & 2.14 & 2.09 & 1.91 & 0.51 & 0.53 & 0.65 & 0.55 \\
\hline
\end{tabular}

${ }^{2}$ Dunnett's values for (A) comparing rowcover means vs. no cover at an irrigation treatment and (B) for comparing irrigation means vs. no irrigation at a level of rowcover. Tukey's w procedure for (A) comparisons among the seven ranked rowcover means at an irrigation level and (B) for comparing two irrigation means at same or different levels of rowcover. All at $P \leq 0.05$.

${ }^{y}$ Rowcovers described in Table 1. 
yields than no cover. Early yields $\left(\mathrm{t} \cdot \mathrm{ha}^{-1}\right)$ were 48 and 28 times higher with PB and PP3, respectively, than with no cover. Rowcovers provided a higher weight of freeze-damaged fruits than no cover. This apparent anomaly can be explained on the basis that more flowers were present where rowcovers were used.

With drip irrigation, $\mathrm{PP} 2, \mathrm{PP} 3, \mathrm{PE}$, and $\mathrm{PB}$ performed similarly and provided better yields than no cover. Fruit yields obtained with the rowcovers were similar when comparisons were made between no cover and drip irrigation.

With sprinkler irrigation, all covers performed similar to the control, except for PA, PP3, and PB, which provided better yields than no cover. When comparisons were made among rowcovers, some overlapping of means occurred. Most covers were similar to each other, except for PA, which was better than PP1. The weight of freeze-damaged fruit amounts with all rowcovers were similar with sprinkler irrigation.

Comparisons of rowcovers with the no-cover treatment at levels of irrigation were important. However, also of interest were comparisons of rowcovers without irrigation with sprinkler irrigation alone (the standard grower practice). PP1, PP2, PP3, PT, and PB provided early yields similar to sprinkler irrigation alone (Dunnett's value $\left.=0.51 \mathrm{t} \cdot \mathrm{ha}^{-1}\right)$.

Total-season yield. Total marketable and cull fruit yields were not affected significantly by irrigation method or rowcover (data not shown). The mean number of marketable and cull fruits were 945,000 and 265,000 fruits/ha, respectively. The mean marketable and cull fruit yields were 13.3 and $1.6 \mathrm{t} \cdot \mathrm{ha}^{-1}$, respectively. Marketable yields of $13.3 \mathrm{t} \cdot \mathrm{ha}^{-1}$ would be considered excellent for a 4month harvest season in northern Florida (Florida Crop and Livestock Reporting Service, 1990). Treatments interacted in their effects on number, weight, and percentage of freeze damaged fruit for the total season. With no irrigation; yields of freeze-damaged fruits for the season were higher with any rowcover than with no cover (Table 4). Among rowcovers, performance was similar, except that more freeze-damaged fruits resulted under PB compared to PE. Under drip irrigation, rowcovers performed similarly to each other and all rowcovers resulted in a higher weight of freeze-damaged fruit than no cover. Under sprinkler irrigation, plants covered with PA, PP3, and PE produced more $\left(\mathrm{t} \cdot \mathrm{ha}^{-1}\right)$ freeze-damaged fruits than no cover.

\section{Discussion}

Sprinkler irrigation provided satisfactory protection of early strawberry fruits, with about $15 \%$ fruit losses to freezing. This amount of loss is similar to that reported in the major strawberryproducing region in Florida and that reported from early research (Locascio et al., 1967). A total of $90 \mathrm{~cm}$ of water was applied to the uncovered, sprinkler-irrigated plants in this study; this amount represents $\approx 50 \%$ of the total water used by many commercial strawberry growers.

Drip irrigation, operated under the mulch or a cover during a freeze event, resulted in negligible protection above that from the mulch or a rowcover alone. The practice of operation of a drip system during a freeze to provide heat that could be trapped by a rowcover or mulch was not effective and could result in fertilizer leaching during extended freezes.

With no irrigation, early marketable fruit yield was better with PP1, PP3, and PB than with no cover. PP3 and PB were heavy covers; PP1 was light. Good yields with PP1 could have resulted from a combination of growth enhancement (higher temperatures) (Wells and Loy, 1985) and freeze protection.
Several rowcovers, (PP1, PP2, PP3, PT, and PB) used alone had the capacity to provide freeze protection equivalent to sprinkler irrigation. Protection of fruit yield with these covers was equivalent to sprinkler irrigation and resulted in savings of $90 \mathrm{~cm}$ of irrigation water along with its associated costs in terms of power for pumping, fruit losses to water damage, and potential for soil erosion and fertilizer leaching. An additional benefit from rowcover protection in contrast to irrigation was that harvesters could enter the field sooner after a freeze and equipment traffic was facilitated in the drier field.

Plants subjected to severe freezes, resulting in fruit losses early in the season, recovered quickly and produced similar total yields as plants that were protected throughout the season. This response of yield recovery of freeze-exposed plants had already been observed by Locascio et al. (1967). Although freeze-exposed plants recovered, the yield was later in the season and at a period when prices were low.

Our results were similar to those of Poling et al. (1991) in North Carolina, where rowcovers protected early yield; however, the interpretation for Florida is different. In the North Carolina study, harvest did not begin until 25 Apr., whereas, in Florida, harvest began in December and the plants were subjected to many freezes during the fruiting phase of growth. For southern areas of the United States, such as Florida, early fruiting commands higher market prices and would justify rowcover use. Early (December) strawberries can be worth $\$ 4 / \mathrm{kg}$, while later strawberries (March and April) are often worth only $\$ 1 / \mathrm{kg}$.

Rowcovers (e.g., PP3) would cost about $\$ 3000$ to $\$ 4000 /$ ha for the materials and would be usable for at least three seasons. In commercial field trials of rowcover technology, a crew of 12 needed $\approx 45 \mathrm{~min}$ to cover 1 ha. Although rowcovers would be expensive to use, growers employing this technique might realize benefits from rowcovers in addition to the increased early yields. These benefits include easier access to fields after a freeze, fewer fruit losses due to water damage, and capability to protect isolated fields that are subject to power outages during freezes.

\section{Literature Cited}

Albregts, E.E. and CM. Howard. 1984. Strawberry production in Florida. Fla. Agr. Expt. Sta. Bul. 841.

Florida Crop and Livestock Reporting Service 1990. Florida agricultural statistics. Vegetable summary. Fla. Crop and Livestock Rptng. Serv., Orlando.

Harrison, D.S., J.F. Gerber, and R.E. Choate. 1974. Sprinkler irrigationfor cold protection. Fla. Coop. Ext. Serv. Circ. 348.

Hochmuth, G.J., S.R. Kostewicz, S.J. Locascio, E.E. Albregts, C.M. Howard, and C.D. Stanley. 1986. Freeze protection of strawberries with floating rowcovers. Proc. Fla. State Hort. Soc. 99:307-311.

Hochmuth, G.J. (ed.). 1988. Strawberry production guide for Florida. Fla. Coop. Ext. Serv. Circ. 141.

Hochmuth, G., D. Maynard, C. Vavrina, and E. Hanlon. 1991. Plant tissue analysis and interpretation for vegetable crops in Florida. Fla. Coop. Ext. Serv. Spec. Ser. SS-VEC-42.

Locascio, S.J., D.S. Harrison, and V.F. Nettles. 1967. Sprinkler irrigation of strawberries for freeze protection. Proc. Fla. State Hort. Soc. 80:208211.

Poling, E.B., H.P. Fuller, and K.B. Perry. 1991. Frost/freeze protection of strawberries grown on black plastic mulch. HortScience 26:15-17.

Steel, R.G.D., and J.H. Torrie. 1960. Principles and procedures of statistics. McGraw-Hill, New York.

Wells, O.S. and J.B. Loy. 1985. Intensive vegetable production with rowcovers. HortScience 20:822-826. 